\title{
worldview
}

A JOURNAL OF RELIGION AND INTERNATIONAL AFAIRS

\section{THE MIKOYAN CONTROVERSY}

Deputy Premier Anastas I. Mikoyan has returned to the Soviet Union but he has left us with controversies that are basic in East-West relations. Apart from any judgment on the success of the Milkoyan visit-either from his point of view or from ours-American opinion is divided, in some cases bitterly, over the political and the moral propriety of the reception which the Russian leader received.

Congressman Walter $\mathrm{H}$. Judd of Minnesota raised the moral issue at the beginning of $\mathrm{Mr}$. Mikoyan's "holiday" when he announced that he would not attend a dinner to honor one of the perpetrators of the Hungarian butchery. Mr. George Meany, president of the AFL-CIO, declined in similar terms. Archbishop Hurley of Florida kept Mikoyan out of his diocese by announcing that if the Deputy Premier should enter it the bells of all the Catholic churches would toll for Hungary's dead. And after Mr. Mikoyan had departed these shores, Richard Cardinal Cushing, Archbishop of Boston, expressed grief and amazement over the friendliness with which a Communist leader was greeted in some of America's best capitalist circles.

The moral case against the Mikoyan visit was sharply drawn in the January 31 issue of America, the weekly review edited by the priests of the Society of Jesus. Editorially, the magazine charges that "never did the smooth pitch and the soft sell gloss over so many big lies and cosmic distortions." In the same issue, under the subhead "Hats off to a Butcher," Mr. Christopher Emmet writes: "The critics of the reception given Mikoyan do not oppose serious negotiations with the Soviet Union. What they do object to is fratemization with the spokesman of a bloodyhanded dictatorship which is responsible for the torture and death of untold tens of millions, which holds 100 million East Europeans in bondage today, and which has placed a gun at our own heads at this very moment by its ultimatum on Berlin."

As it has been stated, the moral position against the amenities which surrounded Mr. Mikoyan in America seems impregnable. Broken Soviet promises, slave labor camps, the Hungarian massacre, the Berlin ultimatum: who but a cynic could "welcome" a man so closely associated with such things? And who but a fool could be deceived into thinking that such a man, because he can smile, is really, at heart, some kind of liberaldemocrat?

But on examination the moral issues involved in this and similar cases seem more complex than a recital of the Soviet Union's and Mr. Mikoyan's enormities indicates. Considering these crimes in themselves one must, of course, take a "moral" stand: one does not "fraternize" with people like this. But considering the question-enormities and all-within the wide and perilous context of the present world situation, one at least suspects that too proper, too pure a "moral" stance might trap us in that irrelevance and irresponsibility which is a form of political immorality. The unpleasant truth about today's world is that we have a moral duty to negotiate and even-when it is necessary-fraternize with people for whom we can feel nothing but horror.

We cannot approve of Mr. Mikoyan; we probably can approve of Mr. Khrushchev even less. But they represent a powerful political block and the whole future of the race may depend on our ability to achieve some stable modus vivendi with them. And the most informed opinion on the mysteries of Soviet power believes that if Khrushchev and Mikoyan should fall, they will be replaced by men we will find even more distasteful, and with whom a modus vivendi will be even less likely.

"Morality," narrowly conceived, can mean a final immorality. We all stand under one great imperative in the international order today: to achieve that measure of accommodation between hostile powers that will avert the ultimate war. To that end a good deal of fraternizing-much more than we have yet had-will most certainly be necessery. 